\title{
Oromucosal Spray, Emulsion Dosage
}

\section{Form}

National Cancer Institute

\section{Source}

National Cancer Institute. Oromucosal Spray, Emulsion Dosage Form. NCI Thesaurus.

Code C149741.

Liquid, usually multidose preparation consisting of an emulsion intended for oromucosal use. It is administered by spraying into the oral cavity or onto a specific part of the oral cavity or the throat. It is presented in a container with a spray pump or in a pressurized container with or without a metering valve. 